\title{
LITERASI FINANSIAL PADA TINGKAT SEKOLAH DASAR SEBAGAI STRATEGI PENGEMBANGAN FINANCIAL INCLUSION DI INDONESIA
}

\author{
Abdullah Kafabih \\ UIN Sunan Ampel Surabaya \\ abdullahkafabih@uinsby.ac.id
}

\begin{abstract}
Abstrak
Indeks literasi keuangan Indonesia tahun 2019 menunjukkan nilai yangmasihrendah yakni 38,03\%, ini menandakan rendahnya kemampuan pengambilan keputusan dalam penggunaan dan manajemen uang. Tujuan dari penelitian ini adalah untuk mengetahui strategi pengembangan financial inclusion melalui program literasi keuangan pada siswa sekolah dasar.Siswa sekolah dasar memiliki kecenderungan sikap konsumtif, karenamereka belum dapat membedakan prinsip kebutuhan dan keinginan dalam mengkonsumsi barang.Maka literasi keuangan sebagai bentuk kontrol dan rasionalisasi penggunaan uang.Jenis penelitan ini menggunakan penelitian kualitatif deskriptif dengan pendekatan rasional terhadap literasi keuangan sertapengembangan strategifinancial inclussion.Strategi literasi finansial pada tingkat sekolah dasar belum disusun dengan baik, namun beberapa materi yang memuat tentang literasi keuangan sudah diajarkan pada tingkat sekolah dasar.Pengintegrasian kurikulum, motivasi guru,keterlibatan komunitas, serta penyediaan akses teknologi informasi merupakan faktor-faktor efektif guna meningkatkan pemahaman literasi keuangan.Kurikulum dan materi ajar disesuaikan berdasarkan temuan lapangan yang dirancang para stakeholder terkait terutama aktor pendidikan dankomunitas sosial.Standar konten literasi keuangan sebagai pengembangan keuangan inklusif yakni pelajar dapat memahami hubungan antara pendidikan, karir dan gaya hidup serta pengembangan kemampuan yang dibutuhkan untuk target finansial.
\end{abstract}

Kata Kunci: Sekolah Dasar, Literasi Finansial, Financial Inclussion

\begin{abstract}
Indonesia's financial literacy index in 2019 shows a low value of 38.03\%, indicating the low ability of decision makers in the use and management of money. The purpose of this study was to determine the strategy of developing financial inclusion through financial literacy programs for elementary school students. Elementary school students have a tendency to consumptive attitudes, because they have not been able to distinguish the principle of needs and desires in consuming goods. So financial literacy as a form of control and rationalization of the use of oney. This type of research uses descriptive qualitative research with a rational approach to financial literacy as well as the development of strategic financial
\end{abstract}

MUBTADI: Jurnal Pendidikan Ibtidaiyah

Vol. 2 No. 1, Juli - Desember 2020

P - ISSN : 2715 - 7067

E - ISSN : 2720 - 8850 
inclussion. Financial literacy strategies at the elementary school level have not been well developed, but some material that contains financial literacy has been taught at the elementary school level. Integrating curriculum, teacher motivation, community involvement, and providing access to information technology are effective factors to improve understanding of financial literacy. Curriculum and teaching materials are adjusted based on field findings designed by relevant stakeholders, especially educational actors and social communities. Financial literacy content standards as development inclusive finance that is, students can understand the relationship between education, career and lifestyle and the development of skills needed for financial targets.

Keywords: Elementary School, Financial Literacy, Financial Inclusion

\section{PENDAHULUAN}

Sejak dimunculkannyaStrategi Nasional Literasi Keuangan Indonesia pada tahun 2011, Indonesia telah mengalami peningkatan financial inclussionyang cukup signifikan. Survei OJK pada tahun 2016 tingkat literasi keuangan di Indonesia yaitu 29,7\% dan indeks inklusi keuangan 67,8\%, tingkat literasi keuangan meningkat menjadi 38,03\% dan indeks inklusi keuangan mencapai 76,19\% pada 2019 (OJK:2019) Determinan utama peningkatan inklusi keuangan di Indonesia diantaranya faktor karakteristik individu seperti tingkat pendapatan, tingkat pendidikan, dan umur secara signifikan berpengaruh terhadap kepemilikan akun institusi keuangan. (Nugroho \& Purwanti, 2017).

Pemilik akun institusi finansial diatas usia 15 tahun turut meningkat,pada tahun 2011 berjumlah 19,6 \%kemudian mengalami peningkatan signifikan pada tahun 2014 menjadi 36,1\% dari jumlah penduduk, maka totalnya berjumlah 48,9\% di tahun 2019 . Namun jumlah ini masih dibawah rata-rata Negara Asia pasifik, yakni 70,6\%.(The World Bank, 2018).Jumlah akun instansi finansial dan akun juga masih terbatas, minimnya tingkat literasikeuangan juga disebabkan faktor rendahnya tingkat pendidikan.Perlu adanya upaya untuk mengintegrasikan literasi keuangan terutama bagi anak-anak usia 15 tahun kebawah, sehingga dapat meningkatkan keuangan yang inklusif bagi semua kalangan.Keuangan inklusif di Indonesia selain berfungsi sebagai perluasan akses keuangan, juga diperlukan sebagai upaya pemberdayaan masyarakat agar dapat mengakses jasa keuanganmelalui pengaturan kolateral yang lebih sederhana serta penjaminan pinjaman. Keuangan inklusif dipengaruhi oleh kemampuan literasi keuangan maka beberapa faktor terkait harus terintegrasi agar memiliki dampak signifikan.

Literasi finansial didefinisikan sebagai kemampuan untuk membuat penilaian berdasarkan informasi, serta membuat keputusan yang efektif terhadapsumber dana yang dimiliki(Greenspan, 2006). Beberapa penelitian mengasosiasikan rendahnyaliterasi 
keuangan menyebabkan inklusi keuangan tidak dapat berkembang.Menurut Gilberto inklusi keuangan merupakan salah satu strategi penting pertumbuhan ekonomi yang inklusif, bahwa dengan pendidikan dan regulasi pemerintah akan mampu mempercepat keuangan inklusif. (Llanto, 2015).Sementara menurut Budiana semakin tinggi tingkat pendidikan berdampak pada kemampuan literasi keuangan (Gomulia et al., 2020).Penanaman nilai-nilai literasi keuangan sedini mungkin pada anak-anak tingkat sekolah dasar berpengaruh terhadap pemahaman dan pengetahuan tentang literasi keuangan serta tingkat kesejahteraan di masa yang akan datang.

Pendidikanliterasi keuangan sangat penting untuk diterapkan pada anak sedini mungkin.Seperti halnya pendidikan secara umum, pendidikan keuangan merupakan sebuah proses yang dapat dimulai sejak dini, akumulasi proses ini akan membentuk kemampuan seorang anak untuk menetapkan sebuah keputusan finansial. Keputusan finansial dapat berdampak pada bagaimana cara memperoleh akses pendidikan, aset properti dan tabungan yang dapat meningkatkan kesejahterannya.(Greenspan, 2006)kemampuan kognitif adalah faktor fundamental yang dapat mempengaruhi kemampuan literasi keuangan dimana pada tahap perkembangan sangat efektif,guna menanamkannilai-nilai literasi keuangan..

Institusi sekolah berperan penting sebagai lingkungan akademik yang efektif memberikan pengetahuan pendidikan literasi keuangan pada anak. Komitmen bersama serta sinergitas semuapihak sangat dibutuhkan untuk kesuksesan penanaman nilai-nilai literasi keuanganmelalui keluarga ataupun sekolah (Subroto: 2011). Menurut Laila (2019) implementasi literasi keuangan dapat dilakukan dengan mengajarkan pendidikan literasi finansial sesuai dengan kompetensi dasar yang sudah ada pada mata pelajaran, seperti Matematika dan IPS. Guru dapat mengajarkan materi ekonomi dan ilmu sosial sebagai bentukusaha menyejahterakan kehidupan masyarakat dengan mengenalkan jenis usaha serta melakukan kegiatan membuat sebuah karya dan menjualnya.

Pemerintah Indonesia melalui Bank Indonesia sejak tahun 2011 Bank Indonesia (BI),telahmenunjukkan keseriusannya menjalankan program inklusi keuangan dengan menggelar program edukasi keuangan. Bank Indonesiabersama dengan Kementerian Pendidikan Nasional menyusunstandar kurikulum keuangan inklusif di tingkat sekolah dasar dan menengah.Edukasi keuangan merupakan satu dari lima pilar penopang kebijakan financial inclusion. Empat lainnya adalah, peningkatan kapasitas masyarakat memperoleh layanan keuangan, regulasi yang mendukung, peningkatan intermediasi, dan reformasi kebijakan. Terakhir ini meliputi perlindungan nasabah, agent banking, dan phonebanking. (Bernadette:2011)

Beberapa perubahan strategi dilakukan oleh pemerintah untuk meningkatkan literasi keuangan, salah satunya tercermin dalam Stratetegi Nasional Literasi Keuangan Indonesia (SNLKI).Jika mengacu pada SNLKI 2013 prioritas sasaran target ditentukan setiap tahunnya, dengan sasaran target pencapaian yang berbeda tiap tahunnya (ibu rumah 
tangga, pelajar/mahasiswa, karyawan pensiunan). Perubahan strategi selanjutnya yaitu revisit SNLKI 2017 dengan target prioritas tahunan ditentukan oleh OJK, bersama dengan industri jasa keuangan. Perubahan strategi tersebut dengan mempertimbangkan kesamaan kebutuhan literasi dan inklusi keuangan.Beberapa hal baru yang terdapat dalam revisit SNLKI 2017 diantaranya terkait literasi dan inklusi keuangan syariah, informasi terkait layanan keuangan digital, serta perencanaan keuangan. Hal mendasar yang perlu diperhatikan dalam peningkatan strategi, tersebut yaitu rumusan strategi terkait literasi keuangan pada pendidikan tingkat dasar.

Pelaksanaan pendidikan literasi keuangan pada siswa sekolah dasar dapat memberikan sikap positif siswa untuk berpartisipasi dalam kegiatan produksi dan memotivasi siswa untuk menabung. Guru dapat mengajarkan pendidikan literasi finansial sesuai dengan kompetensi dasar yang sudah ada pada mata pelajaran, seperti Matematika dan IPS. Guru dapat mengajarkan materi peran ekonomi dalam upaya menyejahterakan kehidupan masyarakat dengan mengenalkan jenis usaha serta melakukan kegiatan membuat sebuah karya dan menjualnya. (Laila \& Hadi, 2019) Program peningkatan kemampuan literasi finansial bertujuan untuk memberikan pemahaman kepada siswa, khususnya tanggung jawab akan pengelolaan uang yang dimilikinya.Kemampuan mengelola keuangan pribadi dibutuhkan individu baik di masa sekarang maupun di masa depan untuk memanfaatkan produkkeuangan secara optimal yang akan berpengaruh terhadap kualitas manusia.

Namun implementasi yang ada di lapangan menunjukkan bahwa program literasi keuangan belum sepenuhnya dijalankan dengan efektif, terutama terkait mekanisme pembelajaran yang berimplikasi pada peningkatan kemampuan literasi keuangan.Penggunaan standarisasi kurikulum dan bahan ajar yang aplikatif dalam memahami dan menjalankan program literasi keuangan belum dijalankan. Strategi peningkatan literasi finansial bagi anak-anak akan meningkatkan keuangan inklusif. Pengembangan strategi ini juga akan mampu memberdayakan masyarakat yang rentan akan krisis ekonomi.

\section{METODE}

Jenis penelitan ini menggunakan penelitian kualitatif deskriptif.Peneliti bertindak sebagai pengamat nonpartisipan dankehadiran peneliti diketahui oleh narasumber. Subjek penelitian yang digunakan yaitu guru sekolah dasar pada empat sekolahSDIT Daarul Muttaqien, SDK ST. Mary, SDI Yamasa, dan SD Muhammadiyah 21 Surabaya.Satuan analisis yang digunakan untuk mengkajisetiap pokok pembahasan dilakukan dengan meninjau tema pembahasan berdasarkan pendekatan ekonomi. Dalam konteks ini penulis menelaah teoritik literasi keuangan secaraemprik memperoleh kebenaran empirik pula. 
Dalam hal ini, disiplin yang ditelaahyakni tentang evaluasi kemampuan siswa, dilanjutkan kemudian dengan konsepdan strategi literasi keuangan di sekolah dasar

Teknik pengumpulan data yang digunakan, yaitu wawancara dan observasi. Data observasi diperoleh dari kegiatan pelaksanaan literasi finansialselama pembelajaran di kelas dan kegiatan tindak lanjut. Data dokumentasi yang diambil yaitu rencana pelaksanaanpembelajaran, potret kegiatan pendidikan literasi finansial dan sarana penunjang literasi finansial. Penelitian melakukanpenelitian di sekolah dasar sampai peneliti memperoleh data jenuh dan menemukan jawaban yang konstan sesuai fokuspenelitian. Analisis data yang digunakan dalam penelitian ini yaitu organisasi data, pembacaan data (memoing), mendeskripsikan data menjadi kode, mengklasifikasikan coding ke dalam tema, menafsirkan data, dan menyajikan data(Cresswell, 2018).

Gambar 1.Kerangka Konseptual

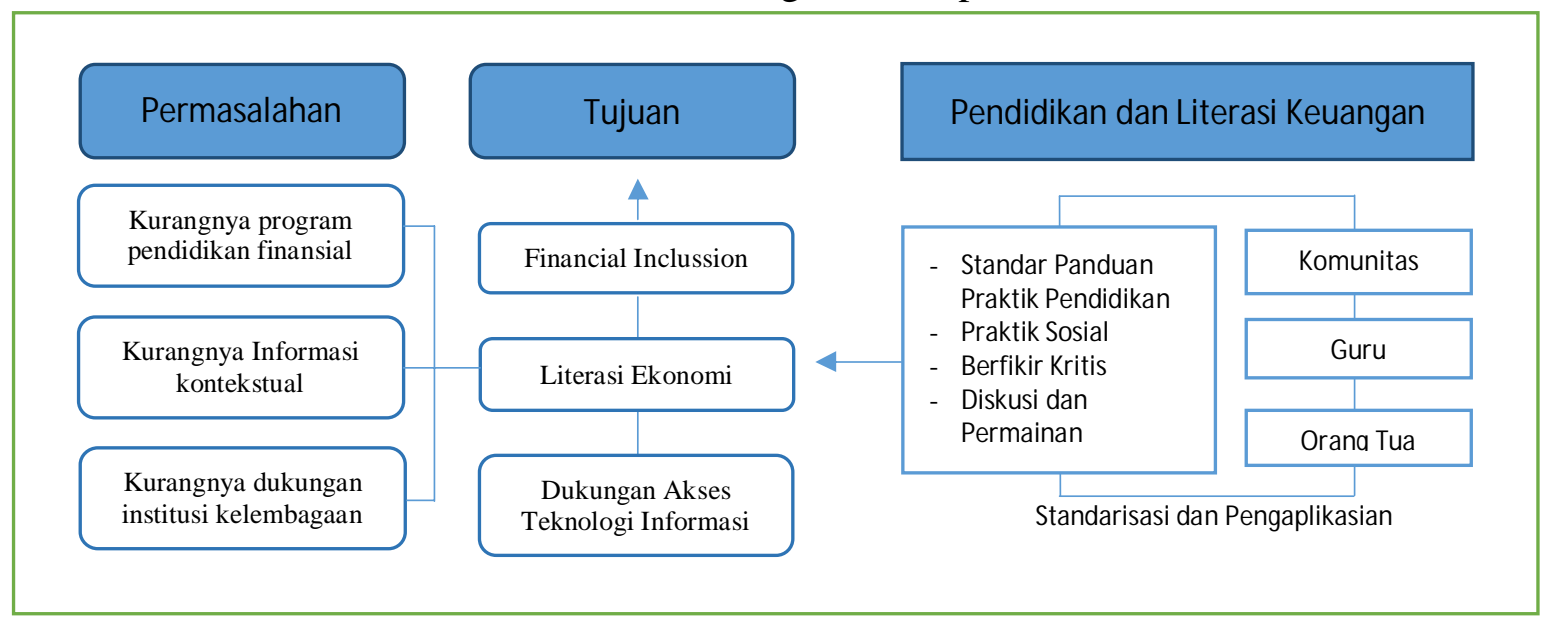

\section{HASIL PENELITIAN DAN PEMBAHASAN}

Membangun ekosistem keuangan finansial terutama bagi semua kalangan, telah menjadi perhatiandunia, terutama bagi masyarakat berpendapatan rendah.Upaya peningkatan keuangan inklusif merupakan salah satu strategi dalam meningkatkan pertumbuhan yang inklusif.Kunci permasalahan mengapa sistem keuangan formal tidak inklusif disebabkan karena belum terintegrasinya keuangan inklusif serta kemampuan literasi keuangan kedalam pendidikan serta regulasi terkait.

Menurut Organisation for Economic Co-operation and Development atau OECD (2016) literasi keuangandidefinisikan sebagai pemahaman serta pengetahuan atas teori dan resikotransaksi keuangan, serta keterampilan pengelolaan, motivasi, sertakeyakinan untuk menerapkan pengetahuan dan pemahaman yang dimilikinya tersebut dalam rangka membuatkeputusan keuangan yang efektif, bertujuan meningkatkan kesejahteraan 
keuangan personal danmasyarakat, dan setiap individu dapat ikut serta dalam bidang perekonomian.

Pemahaman keuangan sangat penting gunamembuat suatu keputusan dalam meningkatkan kesejahteraan finansialnyaserta berjaga-jaga dari kondisi krisis ekonomi.Beberapa konsep literasi terapan sudah diaplikasikan dan diintegrasikan kedalam kurikulum pembelajaran sekolah dasar diantaranya yaitu nilai antikorupsi.Pengenalandan pengetahuan terkait nilai-nilai anti korupsi sudah dilakukan oleh beberapa institusi hukum seperti kejaksaan, Komisi Pemberantasan Korupsi dan dilaksanakan oleh institusi pendidikan dengan memasukkan nilai-nilai antikorupsi tersebut dalampembelajaran tertentu, misal Pendidikan Agama, moral dan pancasila, Ekonomi, dan lainnya. Namun pengetahuan literasi keuangan masih dilakukan oleh beberapa pihak saja sepertiOtoritas Jasa Keuangan bersama Bank Indonesia.Peningkatan pengetahuanterkaitliterasi keuangan dan nilai-nilai korupsi merupakan salah satu bentuk investasi sosial untukmeningkatkan modal manusia Indonesia ke depan yang hendaknya dapat diimplementasikan tidak hanya di kalangan akademik saja namun juga dalam konteks kemasyarakatan.(Wahyuny, 2015)

Pada tingkat dasar konsep literasi finansial dapat dimasukkan dalam pembelajaran matematika dan ilmu sosial.Literasi finansial juga dapat dimasukkan dalam bentuk permainan atau program pengembangan minat dan bakat.Berdasarkan data dari Otoritas Jasa Keuangan (2019) sesuai tingkatan wilayah, untuk masyarakat perkotaan indeks literasi keuangan mencapai $41,41 \%$ dan tingkat financial inclusion masyarakat perkotaan sebesar $83,60 \%$, sementara indeks literasi dan financial inclusionmasyarakat perdesaan adalah $34,53 \%$ dan 68,49\%.Berdasarkan dari data global findex disebutkan bahwa jumlah akun finansial yang adadi Indonesia sebesar 48,9\%, nilainya masih cukup rendah jika dibandingkan dengan negara Asia timur dan pasifik yang mencapai 70,6\%.

Tabel 1.Jumlah Akun Institusi Keuangan Indonesia

\begin{tabular}{|l|c|c|c|}
\hline \multicolumn{1}{|c|}{ Data } & Indonesia & East Asia \& Pacific & Lower middle income \\
\hline Jumlah Akun & 48.9 & 70.6 & 57.8 \\
\hline Akun Institusi Finansial & 48.4 & 70.3 & 56.1 \\
\hline Akun Keuangan mobile & 3.1 & 1.3 & 56.1 \\
\hline
\end{tabular}

Sumber: Global Findex Indonesia

Walaupun inklusi keuangan telah mengalami peningkatan, namun peningkatan literasi keuangan untuk anak diharapkan akan berdampak pada pengembangan financial inclussion di Indonesia, terutama dengan bergulirnya bantuan pendidikan pada siswa sekolah. Pemberian bantuan tunai dengan tujuan peningkatan modal manusia jika tidak disertai dengan kemampuan literasi finansial akan berdampak negatif terutama pada pembentukan karakter anak pada usia dini. Pengaruh pengalaman konsumen pada saatkecil dan sosialisasi institusi keuanganpada produk tabungan dan instrumen keuangan lebih 
beragam, suatu penelitian menunjukkan bahwa pengalaman penggunaan produk keuangansebelum kuliah dapat menciptakan kebiasaan buruk, atau sikap buruk terhadap manajemen keuanganyang dapat dimitigasi melalui pendidikan keuangan selama kuliah.(Sabri \& MacDonald, 2010)

Terkait strategi pengembangan literasi keuangan, mengacu pada penelitian Nugraha (2019) Strategy to Accelerate Financial Literacy Rate in Indonesia, menunjukkan tahapan strategi literasi keuangan untuk pengembangan keuangan inklusif:

1. Tahap pengembangan strategi melalui, komitmen politik dan dukungan legislasi, strategi nasional literasi keuangan, kelengkapan organisasi dan perencanaan sumberdaya, serta pembangunan karakter dan integritas komunitas keuangan

2. Tahap implementasi strategi melalui kolaborasi dan jaringan kebijakan, pengembangan kurikulum pendidikan formal serta pemberdayaan kaum muda dan inovasi

3. Tahap monitoring dan evaluasi (Nugraha, n.d.)

Komitemen politik untuk memajukan literasi keuangan telah ditandai dengan adanya penetapan strategi nasional literasi keuangan. Peran serta institusi keuangan seperti OJK, Bank Indonesia serta industri keuangan akan sangat membantu kemajuan perkembangan literasi keuangan. Tahapan pengemnbangan strategi melalui kolaborasi dan jaringan kebijakan melalui pendidikan formal diharapkan dapat membantu mengakselerasi pertumbuhan keuangan inklusif di Indonesia.Salah satu program yang dapat diintegrasikan kedalam program literasi finansial salah satunya yakni Program Indonesia Pintar (PIP). Beberapa penelitian tentang implementasi PIP di beberapa daerah menunjukkan, siswa/wali murid tidak dapat menunjukkan bukti penggunaan dana yang telah disediakan. (Rohaeni \& Saryono, 2018), (To et al., 2016)(Prasetiyo, 2018). Diperlukan adanya mekanisme, standar yang mudah dan jelas terhadap pembuktian penyaluran dana PIP serta dana bantuan pada masyarakat lainnya, sehingga tujuan penggunaan dana serta peningkatan pemahaman literasi keuangan bagi siswa bisa dijalankan dalam satu kerangka tujuan. Implementasi khususnya pada anak didik yang telah mendapatkan dana dari program PIP tersebut. Melalui instrumen PIP pemerintah dapat mengedukasi siswa terkait bagaimana penggunaan, pengelolaan dan pertanggung jawaban dana yang telah diberikan. Siswa akan memiliki nilai kesadaran dan pemahaman tujuan penggunaan dana. Integrasi kurikulum, proses belajar mengajar, serta implementasi sederhana diharapkan dapat meningkatkan inklusi keuangan di Indonesia.

Peserta didik SD/MI/Paket A mendapatkan dana dari Program Indonesia Pintar sebesarRp450.000,-/tahun. Program ini disusun untuk membantu anak-anak usia sekolah dari keluarga miskin/rentan miskin/prioritas tetap mendapatkan layanan pendidikan sampai tingkat pendidikan menengah, baik melalui jalur pendidikan formal. Dana tersebut dapat 
digunakan untuk membantu biaya pribadi peserta didik, seperti membeli perlengkapan sekolah/kursus, uang saku dan biaya transportasi, biaya praktik tambahan serta biaya uji kompetensi. Walaupun dana ini digunakan untuk membantu penyelenggaraan pendidikan, namun beberapa temuan di lapangan menunjukkan dana tersebut lebih banyak digunakan untuk hal-hal yang bersifat konsumtif. Anak belum dapat membedakan antara kebutuhan dan keinginan, serta faktor ekonomi dari orangtua juga berpengaruh terhadap perilaku keuangan anak.

Faktor 'terapan' adalah elemen penting dalampendidikan keuangan yang efektif, karena ketika siswa atau orang tua siswa menerapkan pengetahuan dan keterampilan baru, dia meningkatkan peluang untuk tetap mempertahankan kemamapuan dasar tersebut. Karena itu,beberapa peluang terbaik dalamliterasi keuangan terjadi ketika kelompok sasaran menghadapi situasi atau keputusan keuangan baru.(Nelson \& Advisor, 2011)Program-program keuangan yang telah ada pada sekolah dasar dapat diintegrasikan kedalam penerapan literasi keuangan. Sistem koperasi, kantin sekolah, tabungan kelas serta berbagai komponen terkait dapat diintegrasikan sebagai strategi pengembangan edukasi keuangan. Anak-anak akan terbiasa memanfaatkan lingkungan sekolah sebagai media pembelajaran yang aplikatif dan dapat diterapkan di masa depan.

Pengembangan literasi keuangan juga dapat dimasukkan dalam kegiatan ekstra di luar jam pelajaran. Program menabung dan cara cermat membelanjakan uang saku memungkinkan adanya efisiensi dan kemampuan literasi keuangan siswa akan meningkat. Selain menyimpan dan membelanjakan uang siswa juga perlu diajarkan proses mendapatkan sumber dana tersebut, misalnya dengan memperkenalkan berbagai jenis profesi usaha, jenis resiko serta tingkat pendapatannya.

Berdasarkan penggalian data yang dilakukan pada empat sekolah di Surabaya,menunjukkan bahwa strategi literasi finansial pada tingkat sekolah dasar belum disusun dengan baik, seperti belum terintegrasinya kurikulum serta strategi pembelajaran terkait literasi keuangan. Beberapa materi yang memuat tentang literasi keuangan sudah diajarkan pada tingkat sekolah dasar, materi literasi keuangan yang telah diajarkan antara lain yakni fungsi dan nilai mata uang, peran institusi keuangan seperti bank dan koperasi, serta fungsi dan tujuan menabung.

Hasil evaluasi dari kemampuan para siswa terkait literasi keuangan menunjukkan bahwa, siswa sudah memahami dan terbiasa untuk melakukan aktivitas keuangan seperti menabung dan memahami fungsi institusi keuangan seperti bank. Siswa juga telah terbiasa melakukan donasi dari sebagian uang sakunya untuk membantu orang lain. Beberapa kemampuan ini merupakan kemampuan dasar dalam literasi keuangan yakni kemampuan dalam mengaplikasikan, memahami serta mengelolainformasi untuk membuat suatu keputusan finansialnya. 
Siswa dengan kemampuan pengetahuan tentang keuangan yang lebih tinggicenderung aktif terlibat dalam perilaku menabung, sementara siswa dengan pengaruh sosialisasi keuangan yang lebih rendah konsumen masa kecil mereka cenderung kurang aktif dalam kebiasaan menabung.(Sabri \& MacDonald, 2010)

Kemampuan literasi keuangan belum sepenuhnya dapat diajarkan kepada para siswa seperti penyampaian informasi terkait pencatatan transaksi keuangan, tujuan dan aktivitas keuangan seperti pembayaran biaya seperti tagihan listrik dan air, fungsi investasi, serta tujuan memproduksi barang dan jasa termasuk laba-rugi dan penggunaan modal. Pemberian materi produk-produk keuangan diarahkan pada tingkat perkembangan kemampuan kognitif dan psikologiskesiapan akan dengan mudah melibatkan pemahaman siswa tentang menunda kepuasan, menabung,mendapatkan atau membayar bunga, dan dasar-dasar keuangan pribadi lainnya.(Sabri \& MacDonald, 2010)

Pendidikan menjadi salah satu determinan penting yang dapat menjadi sarana bagi peningkatan inklusi keuangan di Indonesia. Selain memasukkan materi terkait literasi keuangan kedalam kurikulum pembelajaran sekolah juga dapat memberikan materi tersebut diluar jam belajar.Peningkatan literasi keuangan akan berdampak pada peningkatan akses masyarakat terhadapa layanan keuangan, selain itu peningkatan literasi keuangan juga berdampak pada ruang lingkup yang lebih luas diantaranya:

1. Manfaat individu : keuntungan pengembangan ekonomi individu, menghidari hutang konsumtif, mempersiapkan kesipan kesehatan/mental

2. Manfaat sosial : meningkatkan peluang di tempat kerja, dorongan etika finansial, kesiapan dalam menghadapi guncangan finansial

3. Manfaat nasional : Pengembangan pasar finansial, memperkuat stabilitas sektor keuangan, mengurangi beban keamanan sosial, dukungan terhadap indeks pembangunan manusia yang lebih baik, efisiensi, transparansi serta praktek kompetitif institusi finansial.

Masyarakat perlu diberikan pemahaman terkait persoalan keuangan sedini mungkin.Melalui pengembangan kurikulum pendidikan formal yang terintegrasi dengan mata pelajaran matematika, sosial dan kewarganegaaan dapat diberikan pada tingkat pendidikan dasar.Pemberdayaan kaum muda dan inovasi, dapat dikembangkan melalui tekonologi seperti yang dilakukan di Brazil.Brazil memperkenalkan inovasifinancial soccer sebagai media pembelajaran yang efektif bagi penduduknya. SP Jain Schoolof management akan menjadikan program pendidikannya mereka menjadi program Virtual Reality pertama di dunia pada tahun 2017(Nugraha, n.d.). Inovasi pembelajaran dengan menggunakan perangkat teknologi dapat dijadikan instrumen sehingga anak lebih mudah menangkap pelajaran.Beberapa aplikasi gawai dan website yang tersedia memungkinkan anak belajar mandiri walaun sedang tidak berada pada lingkungan sekolah.Pendampingan dan pengawasan dari beberapa komunitas siswa juga harus tetap diperhatikan. 
Terdapat beberapa prinsip yang dapat digunakan untuk pengembangan program literasi keuangan yang efektif, diantaranya yakni:

1. Terdapat visi dan misi yang jelas, target yang spesifik terkait tujuan dari program literasi keuangan akan membuat menjadi lebih efektif.Target literasi terapan pada siswa kelas 6 yang sudah mampu melakukan pencatatan transaksi keuangan sederhana pada akhir pembelajaran.

2. Terhubung pada standarbaku, menurut standar akademik Wisconsin Model, terkait literasi finansial individu. Institusi pendidikan dapat mengikuti aturan program literasi keuangan yang komprehensif. Standar konten yang dapat menjelaskan bagaimana tahapan pembelajaran, serta apa saja yang harus dicapai dalam program tersebut diantaranya:

Tabel 2

Standar Konten Literasi Keuangan

\begin{tabular}{|c|c|c|c|}
\hline $\begin{array}{c}\text { Standarisasi } \\
\text { Konten }\end{array}$ & Tahap 1 & Tahap 2 & Tahap 3 \\
\hline \multirow{3}{*}{$\begin{array}{l}\text { Pelajar dapat } \\
\text { memahami } \\
\text { hubungan } \\
\text { antara } \\
\text { pendidikan, } \\
\text { karir dan gaya } \\
\text { hidup serta } \\
\text { pengembangan } \\
\text { kemampuan } \\
\text { yang } \\
\text { dibutuhkan } \\
\text { untuk target } \\
\text { finansial }\end{array}$} & $\begin{array}{l}\text { Memahami } \\
\text { bagaimana pilihan } \\
\text { profesi, edukasi, } \\
\text { skil, kewirausahaan } \\
\text { dan kondisi } \\
\text { ekonomi berdampak } \\
\text { pada pendapatan }\end{array}$ & $\begin{array}{l}\text { Memahami bagaimana } \\
\text { pilihan profesi, edukasi, skil, } \\
\text { kewirausahaan dan kondisi } \\
\text { ekonomi berdampak pada } \\
\text { pendapatan }\end{array}$ & $\begin{array}{l}\text { Memahami bagaimana pilihan } \\
\text { profesi, edukasi, skil, } \\
\text { kewirausahaan dan kondisi } \\
\text { ekonomi berdampak pada } \\
\text { pendapatan }\end{array}$ \\
\hline & $\begin{array}{l}\text { Waspada terhadap } \\
\text { pemilihan karir, } \\
\text { pendidikan dan } \\
\text { kemampuan yang } \\
\text { berdampak pada } \\
\text { pendapatan }\end{array}$ & $\begin{array}{l}\text { Bagaimana pemilihan karir, } \\
\text { pilihan pendidikan, } \\
\text { kemampuan bisa berdampak } \\
\text { pada pendapatan seseorang }\end{array}$ & $\begin{array}{l}\text { Mengevaluasi dan } \\
\text { mendemonstrasikan bagaimana } \\
\text { pemilihan karir, pilihan } \\
\text { pendidikan, kemampuan/skil, } \\
\text { kewirausahaan dan kondisi } \\
\text { ekonomi berdampak pada } \\
\text { pendapatan }\end{array}$ \\
\hline & $\begin{array}{l}\text { Mengetahui } \\
\text { perbedaan antara } \\
\text { pekerjaan dan karir }\end{array}$ & $\begin{array}{l}\text { Mendeskripsikan } \\
\text { karakteristik unik yang } \\
\text { terdapat pada jenis pekerjaan } \\
\text { dan karir }\end{array}$ & $\begin{array}{l}\text { Menganalisis bagaimana nilai } \\
\text { budaya dan individu dapat } \\
\text { berpengaruh pada keputusan } \\
\text { finansial }\end{array}$ \\
\hline
\end{tabular}

Sumber: (Greenspan, 2006)

Konsep diatas menggunakan taksonomi bloom dan model aplikasi yang bertingkat pada tiap tahapannya. Terdapat beberapa tahapan yang dapat disusun sebagai berikut:

- Tahap 1 :Menjelaskan bagaimana pendapatan mempengaruhi pengeluaran

- Tahap2 :Menguji bagaimana pendapatan seseorang akan berdampak pada pemilihan dan keputusan pembelanjaan 
- Tahap 3 :Membangun rencana keuangan tentang desain pendapatan yang berdampak pada keputusan pembelian dan pengeluaran

3. Relevansi, semua program terkait literasi keuangan harus relevan. The rigor and relevance merupakan salah satu alat yang digunakan untuk mengetahui perkembangan pengetahuan dengan pengalaman yang menggunakan taksonomi blooms

\section{Tabel 3}

Rigor and Relevance Framework

\begin{tabular}{|l|l|}
\hline \multicolumn{1}{|c|}{ Taksonomi Blooms } & \multicolumn{1}{|c|}{ Model Aplikasi } \\
\hline Kesadaran & Pengetahuan tentang kedisiplinan \\
\hline Pemahaman & Mengaplikasikan pengetahuan pada kedisipinan \\
\hline Aplikasi & Mengaplikasikan pengetahuan pada dunia nyata, situasi terkontrol \\
\hline Sintesis & $\begin{array}{l}\text { Mengaplikasikan pengetahuan pada dunia nyata, situasi tidak } \\
\text { terkontrol }\end{array}$ \\
\hline Evaluasi & $\begin{array}{l}\text { Penilaian otentik menunjukkan aplikasi pembelajaran pada tugas yang } \\
\text { berkaitan dengan tugas sehari-hari di dunia nyata }\end{array}$ \\
\hline
\end{tabular}

Sumber: (Greenspan, 2006)

4. Community-focused, komunitas merupakan komponen esensial yang perlu diperhatikan dalam pengembangan kualitas program literasi keuangan. Selain pendidikan literasi keuangan pada sektor pendidikan formal yaknisekolah dan pendidikan berbasis komunitas masyarakat juga merupakan bagian yang tak terpisahkan. Strategi ini dianggap paling efektif untuk memudahkan integrasi literasi keuanganpada materi pembelajaran yang ada, hal ini bertujuan agar siswa dapat memahami bahwa literasi keuangantidak hanya berguna di dalam kelas, namun menjadi sebuah nilai yang akan berguna di masa depan.

5. Integrasi dengan kurikulum, Program literasi keuangan yang berkualitas menghubungkan semua kurikulum pembelajaran. Guru dapatmenggunakan standar literasi keuangan untuk menyelaraskan kurikulum dan menciptakan kegiatan yang dirancang untuk meningkatkan pengetahuan dan keterampilan siswa.

6. Didukung dengan sumberdaya yang memadai, penggunaan aplikasi digital dan sumber referensi tambahanakan membantu siswa dalam memahami pengetahuan keuangan. Teknologi informasi dan komunikasi lebih berperan efektif untuk meningkatkan inklusi keuangan (Birochi \& Pozzebon, 2016) penggunaan teknologi informasi seperti aplikasi penyimpanan, peminjaman pembayaran digital, dapat diperkenalkan sejak dini sebagai upaya awal dalam mengembangkan literasi keuangan. 


\section{A boullahK adah}

Liter asi Finansial pada Tingkat Sekolah Dasar Sebagai Str ategi Pengemgangan

F inansial Incc usion di Indonessia

7. Evaluasi berkelanjutan, Semua program harus terus dievaluasi efektivitasnya. Evaluasi bisaterdiri dari kinerja siswa pada penilaian sumatif, penilaianformatif, penilaian kebutuhan, dan studi lanjutan.

8. Learner-centered, kurikulum pembelajaran harus fleksibel untuk memenuhi kebutuhan semua siswa. Guruharus memberikan pra-tes untuk menentukan tingkat pengetahuan siswa saat memasuki program. Siswa akan datang ke kelas dengan berbagai latar belakang pengetahuan dan ide mengenai banyak konsep literasi keuangan.

9. Penyampaian efektif, program yang berkualitas melibatkan berbagai strategi pengajaran. Melalui kualitaspengembangan profesional, guru belajar strategi terbaik untuk mengajar literasi keuangan dalam berbagai bidang kurikulum.

Pada tingkat sekolah dasar pengetahuan literasi keuangan harus disusun dengan baik dan aplikatif, sehingga dapat memotivasi siswa untuk mempelajari hal tersebut.Selain itu infrastuktur penunjang seperti sumber belajar serta informasi tentang literasi keuangan dengan memasukkannya dalam muatan pembelajaranyang berkesinambungan. Peran aktif guru untuk mensosialisasikan literasi keuangan seperti sistem tabungan di kelas dan andil kegiatan koperasi bagi siswa akan sangat membantu meningkatkan kemampuan literasi siswa pada tingkat sekolah dasar.Terdapat penelitian yang menunjukkan dampak kemampuan literasi keuangan guru, terhadap efektivitas mereka dalam mengajarkan pendidikankeuangan. Hasil penelitian membuktikan bahwa terdapat korelasi positif antara kemampuan literasi keuangan guru danpengajaran literasi keuangan.(Deng et al., 2013)

Beberapa tahapan yang dapat digunakan pengajar untuk membuat program literasi keuangan menjadi lebih efektif :

- Membuat pemahaman bersama terkait standar literasi keuangan

- Mengidentifikasi permasalahan

- Membuat rencana tindak lanjut

- Desain program

- Implementasi program 
Gambar 2 : Strategi Literasi Keuangan

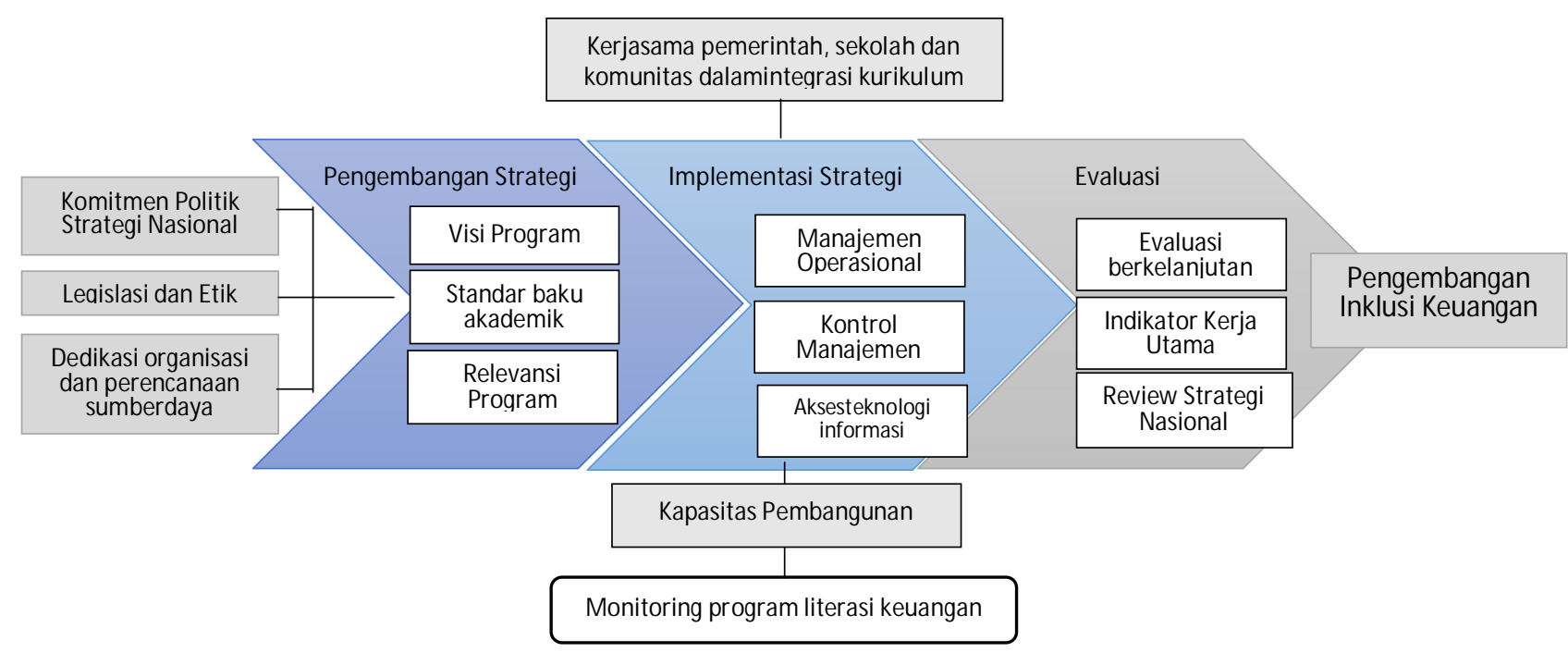

Pengintegrasian kurikulum dan sosialisasi dengan standar baku, serta penggunaan teknologi informasi dan komunikasi diharapkan juga dapat meningkatkan pemahaman siswa.Selain peningkatan inklusi keuangan program literasi keuangan juga dapat memberikan manfaat individu diantaranya dapat mencegah tindakan kejahatan finansial, menghindari hutang konsumtif, meningkatkan kemampuan ekonomi individu, serta kesiapan dalam menghadapi guncangan finansial.Efektivitas pengajaran literasi keuangan sekolah dasar dengan memperluas konsep pembelajaran seperti pemanfaatan dunia digital yang sesuai usia anak-anak. Peneliti memanfaatkan buku bergambar serta cerita yang relevan dengan 'kehidupan nyata' pengalaman siswadan pemahaman konseptual tentang imbalan berinvestasi di masa depan.(Grody, 2015)

Dampak positif hasil penelitian program literasi finansial di tingkat sekolah dasar, dengan menggabungkan unsur-unsur yang dalam kurikulum matematika, ekonomi dan studi sosial.Peran lembaga keuangan dalam penguatan pembelajaranakan mendorong pemahaman siswa, terutama dalam pemberian contoh produk keuangan yang sesuai dengan usia anak-anak sekolah dasar.

Menyediakan program literasi keuangan merupakancara untuk menjembatanikesenjangan ekonomi. Kurangnya program pemberdayaan dan literasi keuangandapat mendorong peningkatanhutang yang disebabkan oleh penggunaan sumber daya yang tidak tepat.Sebagai perantarasolusi, program pendidikan keuangan berdasarkan instrumentalpengetahuan dapat membantu para pengusaha berpenghasilan rendah, strategi literasi keuangan hanya sebagai langkah awal yang harus dilanjukan. 
Evaluasi strategi Sasaran Strategi dari pelaksanaan literasi ekonomi dapat menggunakan pengukuran berdasarkan perspektif balance scorecard. Sasaran strategi merupakan bagian dari strategi seperti yang tercantum dalam peta strategi.Sasaran strategi menggambarkan kegiatan literasi keuangan atau upaya perbaikan/penyempurnaan yang berkelanjutan untuk dapat dilaksanakan dengan berhasil.Organisasi atau institusi memiliki sasaran strategi berdasarkan pada masing-masing perspektif. Perumusan sasaran strategi dapat digambarkan secara ringkas sebagai berikut:

- Perspektif Pelanggan sasaran strategi yaitu: meningkatkan pemahaman keuangan siswa sekolah dasar Perspektif Proses Bisnis Internal Terdiri dari dua sasaran strategi, yaitu: meningkatkan kompetensi para peserta pendidik/guru dengan kemampuan literasi finansial, dan meningkat ketersedian peta mutu dari masing-masing sekolah.

- Perspektif Pembelajaran \& Pertumbuhan (Learning and Growth) Terdiri dari dua sasaran strategi, yaitu: meningkatkan jumlah data tenaga pendidik dan Kependidikan yang memiliki kompetensi literasi keuangan, dan tersedianya data kompetensi yang sesuai kualifikasi.

- Perspektif Keuangan Sasaran strategi yaitu: terpenuhinya kebutuhan pembiayaan program literasi keuangan yang berkelanjutan.

- Indikator Kinerja Utama (IKU) Tolok ukur dalam Balanced Scorecard (BSC) menggunakan Indikator Kinerja Utama (IKU).

\section{KESIMPULAN}

Literasi keuangan merupakan salah satu komponen dalam meningkatkan kualitas sumberdaya manusia, komponen inidigunakan untuk meningkatkan kesejahteraan keuangan.program literasi keuangan juga dapat memberikan manfaat individu diantaranya dapat mencegah tindakan kejahatan finansial, menghindari hutang konsumtif, meningkatkan kemampuan ekonomi individu, serta kesiapan dalam menghadapi guncangan finansial.

Beberapa prinsip yang perluditerapkan untuk pengembangan program literasi keuangan yang efektifdiantaranya terdapat visi dan misi yang jelas, terhubung pada standar baku, semua program terkait literasi keuangan harus relevan, Community-focused, Integrasi dengan kurikulum, sumberdaya yang memadai, evaluasi berkelanjutan, serta learnercentered. Peningkatan inklusi keuangan juga bisa disebabkan adanya dukungan faktor teknologi informasi dan komunikasi.Pembelajaran perlu diarahkan pada literasi terapan yang lebih advokatif, sehingga siswa akan lebih dapat merasakan manfaat dari adanya program literasi keuangan.Standar konten literasi keuangan sebagai pengembangan keuangan inklusif yakni pelajar dapat memahami hubungan antara pendidikan, karir dan gaya hidup serta pengembangan kemampuan yang dibutuhkan untuk target finansial. 
Liter asi Finansial pada Tingkat Sekolah Dasar Sebagai Strattegi Pengemgangan F inansial Inc usion di Indonessia

\section{DAFTAR PUSTAKA}

Deng, H.-T., Chi, L.-C., Teng, N.-Y., Tang, T.-C., \& Chen, C.-L. (2013). Influence of Financial Literacy of Teachers on Financial Education Teaching in Elementary Schools. International Journal of E-Education, e-Business, e-Management and eLearning, 3(1). https://doi.org/10.7763/ijeeee.2013.v3.195

Gomulia, B., Parahyangan, U. K., Barlian, I., Parahyangan, U. K., Dewi, V. I., \& Parahyangan, U. K. (2020). FINANCIAL LITERACY FOR ELEMENTARY. 02(01), 19.

Greenspan, A. (2006). Building an Effective Financial Literacy Program. Building an Effective Financial Literacy Program, 5-18.

http://dpi.wi.gov/sites/default/files/imce/cte/pdf/pflchap1.pdf

Grody, A. D. J. S. E. K. (2015). A Financial Literacy and Financial Services Program for Elementary School Grades - Results of a Pilot Study by A.D. Grody, D. Grody, PhD, E. Kromann, J. Sutliff. SSRN Journal.

Laila, V., \& Hadi, S. (2019). Pelaksanaan Pendidikan Literasi Finansial pada Siswa Sekolah Dasar. 2006, 1491-1495.

Llanto, G. (2015). Financial Inclusion, Education, and Regulation in the Philippines. SSRN Electronic Journal, 541. https://doi.org/10.2139/ssrn.2672722

Nelson, C., \& Advisor, S. T. (2011). Cohenm_Financial_Literacy_39948. Global Microcredit Summit.

Nugraha, U. (n.d.). Strategy to Accelerate Financial Literacy Rate in Indonesia: Best Practices from Selected Countries Strategi Kebijakan Percepatan Tingkat Literasi Keuangan di Indonesia : Studi Praktik Terbaik Beberapa Negara Terpilih. 78-86.

Nugroho, A., \& Purwanti, E. Y. (2017). Determinan Inklusi Keuangan di Indonesia. Departemen IESP Fakultas Ekonomika Dan Bisnis Universitas Diponegoro. https://ejournal.undip.ac.id/index.php/dinamika_pembangunan/article/view/17920/13 120

Prasetiyo, A. B. (2018). IMPLEMENTASI PROGRAM KARTU INDONESIA PINTAR DI SD NEGERI KECAMATAN BATURAJA TIMUR KABUPATEN OGAN KOMERING ULU Skripsi.

Rohaeni, N. E., \& Saryono, O. (2018). Implementasi Kebijakan Program Indonesia Pintar ( PIP ) Melalui Kartu Indonesia Pintar ( KIP ) dalam Upaya Pemerataan Pendidikan. 2(1).

Sabri, M. F., \& MacDonald, M. (2010). Savings Behavior and Financial Problems among College Students: The Role of Financial Literacy in Malaysia | Sabri | Cross-cultural Communication. Crosscultural Communication, 6(3), P103-110. https://doi.org/10.3968/j.ccc.1923670020100603.009

The World Bank. (2018). The Global Findex Database 2017 Indonesia. 1.

To, E., Equitable, A. N., Of, D., Education, A. N., \& Year, L. (2016). IMPLEMENTASI KEBIJAKAN KARTU INDONESIA PINTAR DALAM UPAYA PEMERATAAN 
PENDIDIKAN TAHUN AJARAN 2015 / 2016 DI SMP N 1 SEMIN ( THE

IMPLEMENTATION OF POLICIES INDONESIA SMART CARD IN AN. 21-27.

Wahyuny, I. N. (2015). Pengembangan Pendidikan Financial Literacy Berbasis Nilai- Nilai Anti Korupsi Sebagai Investasi Sosial : Sebuah Pemikiran. Prosiding Seminar Nasional Pendidikan Ekonomi \& Bisnis, November.

https://www.jurnal.fkip.uns.ac.id/index.php/snpe/article/view/7013 